\title{
Sex Determination in Mandibles in the First Year of Life by a Quantitative Approach
}

\author{
Determinación del Sexo en Mandíbulas en el Primer Año de Vida \\ Mediante una Aproximación Cuantitativa
}

*,**Iván Claudio Suazo Galdames; **Daniela Alejandra Zavando Matamala \&** Ricardo Luiz Smith

SUAZO, G. I. C.; ZAVANDO, M. D. A. \& SMITH, R. L. Sex determination in mandibles in the first year of life by a quantitative approach. Int. J. Morphol., 27(1):113-116, 2009.

SUMMARY: Numerous studies have shown that skeletal characteristics vary among different populations. Several authors suggest that it is possible to determine sex through the anatomical evaluation of children mandible, however there are few morphometrical studies conducted with such specimens. The purpose of this study was to analyze several mandibular dimensions and identify the ones that could be useful to perform sex differentiation in a sample of Brazilian young children. For this study we used 32 children dry mandibles of known sex, age ranging from 0 to 1 year old. The mandibles pertain to the collection of the Skull Museum of the Universidade Federal de São Paulo (UNIFESP). The parameters included bicondilar width, bigonial width, minimum width and height of the mandibular ramus, gonion-gnation length, height of the mandibular symphysis and transverse and anteroposterior condylar dimensions. The SPSS program was used to carry on the discriminant function analysis and the $\mathrm{T}$ test $(\mathrm{p}<0.05)$. There were no statistically significant differences that could allow identification of a specific parameter for sex determination. However, most of the dimensions were higher in male than in female, except for the minimum width of the mandibular ramus $(0.2-0.16 \mathrm{~mm})$ and transverse diameter of the right condyle $(0.16 \mathrm{~mm})$. The values obtained for the anteroposterior diameter of the mandibular head were the most different between genders, although no statistically significance was found. Discriminant function analysis indicated that, despite differences, none of the evaluated parameters allow for sex classification with enough reliability. In conclusion, there is little sexual dimorphism in children's mandibles during the first year of life and anatomical analysis of this structure is not recommended as reliable quantitative approach for sex differentiation with forensic purposes.

KEY WORDS: Sexual Dimorphism; Sex determination; Infants; Mandibles.

\section{INTRODUCTION}

The difficulty to determine sex of individuals in children bone remnants is a known problem that limits the anthropological investigations and forensic practice. Several methods have been described for sex diagnosis from postcranial skeleton, particularly the hip bone.

Merrot et al. (2001) used 500 x-ray images of the pelvis of stillborn fetuses and determined that the interischiatic tuberosity distance was a good indicator of sexual dimorphism from 26 week of intra-uterine life. In another study Holcomb \& Konigsberg (1995) analyzed the greater isquiatic notch of human term fetuses and found sexual dimorphism in shape, but not in dimensions, so the usage of the quantitative parameter was questioned as an indicator of sex in fetuses. In contrast, Schutkowski (1993) has reported that men exhibited a greater isquiatic notch closer and deeper than women. These indicators, along with the more prominent chin and the width of dental arch allow to correctly classify $70-90 \%$ subjects between 0 and 5 years old.

The mesiodistal and bucolingual crown dimensions of teeth have also been studied for sex determination in subadults individuals. Cardoso (2008) indicates that, for both adult and subadults, the canines are the pieces that have greater sexual dimorphism. For Rösing (1983), the teeth are only one of the elements that are developed with the adult size and that his dimorphic morphological character is maintained over time.

The mandible also seems to be useful for sex classification in immature skeletons. Loth \& Hennenberg (2001) described a simple, qualitative method for sex

\footnotetext{
* Departamento de Anatomía Normal, Universidad de Talca, Chile

** Departamento de Morfología y Genética. Universidade Federal de São Paulo, Brasil.
} 
differentiation in subadults' mandibules through shape analysis of the mandibular body with $81 \%$ accuracy. These results were discussed by Coqueugniot et al. (2002), who performed a similar study obtaining lower accuracy levels. Subsequently, Suazo et al. (2008a) developed a study with a sample of Brazilian mandibles and reported accuracy levels between 57.5 and $60.5 \%$ for sex determination, with greater sensitivity for determining male, and conclude that it is necessary to carefully evaluate the methods of sex determination from subadults mandibles in specific populations.

Considering this background, the goal of this study is to determine several dimensions of mandibles in a sample of Brazilian children in the first year of life and analyze the reliability of these parameters in sex determination with forensic purposes.

\section{MATERIAL AND METHOD}

We used 32 mandibles of Brazilian children between 0 and 1 year-old, 20 males and 12 females. The mandibles belong to the Skull Museum collection of the Morphology and Genetics Department, Universidade Federal de São Paulo (UNIFESP), Brasil.

The mandibles were separated from the skull, without morphological alterations and no evidence of trauma. Using a digital caliper $(0.01 \mathrm{~mm})$ the following measurements were taken:

- Bicondilar width: Distance between the lateral poles of the right and left mandibular head.

- Bigonial width: Distance between the right and left mandibular angle.

- Minimum width of the mandibular ramus: Minimum distance between the anterior and posterior edge of the mandibular ramus. - Height of the mandibular ramus: distance between the deepest point of the mandibular incisure and the deepest part of the antegonial incisure, is measured in the right and left mandibular ramus.

- Gonion-gnation length: Distance between the mandibular angle and the lowest point of the mandibule in the anterior median line. It is measured from the right and left mandibular angle.

- Height of the mandible: Maximum length of the mandibular median line.

- Transverse dimension of the mandibular head: Distance between lateral pole and medial pole of the mandibular head. It is measured on the right and left side.

- Anteroposterior dimension of the mandibular head: maximum distance between the anterior and posterior face of the mandibular head, measured at right and left sides.
For some mandibles, difficult or doubtful measurements were excluded and only the data obtained were submitted to the $t$ test for independent samples, $p<0.05$ and discriminant function analysis with SPSS 15.0.

\section{RESULTS}

The twelve linear dimensions were analyzed in a sample of 32 mandibles. Due to advanced erosion in one of the mandibles, it was not possible to obtain the measurement of the left mandibular ramus minimum width. In other three male mandibles it was not possible to determine the maximum anteroposterior diameter and the maximum transverse mandibular head.

Most of the measured dimensions were greater in male, except for the minimum width of the left and right mandibular ramus and maximum transverse diameter of the right mandibular. However, none of the differences was statistically significant, meaning that the discriminant analysis procedure was negative. This is verified by the high values of the Lambda Wilks statistics.

The analyzed parameters and statistic analysis are shown in Table I.

\section{DISCUSSION}

To determine the gender of immature skeletons, hip, mandible and teeth seem to be the most useful elements.

The dimorphic traits in children's mandibles, described by Loth \& Henneberg, allow the correct classification of a large number of cases, but are likely to present a population-specific behavior, which may explain the lower accuracy of subsequent studies.

On the other hand, the literature generally assumes that the objective assessment of the skeletal remnants through metric comparisons allows us to obtain better statistical standards of accuracy for age determination and sex diagnosis in forensic and anthropological sciences.

The present study analyzed a series of linear dimensions in children's mandibles and concluded that, despite certain differences, no precise dimorphism could be verified concerning mandible size in the analyzed sample. These findings are consistent with those reported by Franklin et al. (2007), who have used geometric morphometry method 
SUAZO, G. I. C.; ZAVANDO, M. D. A. \& SMITH, R. L. Sex determination in mandibles in the first year of life by a quantitative approach. Int. J. Morphol., 27(1):113-116, 2009.

Table I. Descriptive statistics, and p value of Wilks' lambda of the linear dimensions analyzed in 32 mandibles of children aged between 0 and 1 year old of the collection of UNIFESP.

\begin{tabular}{|c|c|c|c|c|c|c|}
\hline & Sex & n & Mean & SD & Sig. & Wilks' lambda \\
\hline \multirow[t]{2}{*}{ - $\mathrm{B}$ icondilar width } & Male & 20 & 63.1350 & 6.92755 & \multirow{2}{*}{.998} & \multirow{2}{*}{.999} \\
\hline & Female & 12 & 63.1275 & 8.27786 & & \\
\hline \multirow[t]{2}{*}{ - B igonial width } & Male & 20 & 50.4790 & 6.83989 & \multirow{2}{*}{.584} & \multirow{2}{*}{.994} \\
\hline & Female & 12 & 49.1158 & 6.57738 & & \\
\hline \multirow[t]{2}{*}{ - $\mathrm{H}$ eight of the rigth mandibular ramus } & Male & 20 & 19.2510 & 3.96959 & \multirow{2}{*}{.460} & \multirow{2}{*}{.978} \\
\hline & Female & 12 & 18.2325 & 3.26029 & & \\
\hline \multirow[t]{2}{*}{ - $\mathrm{H}$ eight of the left mandibular ramus } & Male & 20 & 18.8530 & 3.84045 & \multirow{2}{*}{.547} & \multirow{2}{*}{.990} \\
\hline & Female & 12 & 18.0408 & 3.28720 & & \\
\hline \multirow[t]{2}{*}{ - $\mathrm{M}$ inimum width of the rigth mandibular ramus } & Male & 19 & 16.9611 & 2.38965 & \multirow{2}{*}{.819} & \multirow{2}{*}{.996} \\
\hline & Female & 12 & 17.1700 & 2.56457 & & \\
\hline \multirow[t]{2}{*}{ - $\mathrm{M}$ inimum width of the left mandibular ramus } & Male & 19 & 17.1247 & 2.31920 & \multirow{2}{*}{.846} & \multirow{2}{*}{.998} \\
\hline & Female & 12 & 17.2933 & 2.35827 & & \\
\hline \multirow[t]{2}{*}{ - $\mathrm{R}$ ight gonion-gnation } & Male & 20 & 40.1245 & 5.37346 & \multirow{2}{*}{.440} & \multirow{2}{*}{.986} \\
\hline & Female & 12 & 38.5642 & 5.60068 & & \\
\hline \multirow[t]{2}{*}{ - L eft gonion-gnation } & Male & 20 & 38.9930 & 5.37810 & \multirow{2}{*}{.709} & \multirow{2}{*}{.997} \\
\hline & Female & 12 & 38.2550 & 5.33035 & & \\
\hline \multirow{2}{*}{$\begin{array}{l}\text { - } \mathrm{T} \text { ransverse dimension of the rigth mandibular } \\
\text { head }\end{array}$} & Male & 19 & 9.0995 & 1.46108 & \multirow{2}{*}{.757} & \multirow{2}{*}{.993} \\
\hline & Female & 12 & 9.2633 & 1.34999 & & \\
\hline \multirow{2}{*}{$\begin{array}{l}\text { - } \mathrm{T} \text { ransverse dimension of the left mandibular } \\
\text { head }\end{array}$} & Male & 20 & 9.2180 & 1.60052 & \multirow{2}{*}{.689} & \multirow{2}{*}{.999} \\
\hline & Female & 12 & 9.0008 & 1.21001 & & \\
\hline \multirow{2}{*}{$\begin{array}{l}\text { - A nteroposterior dimension of the rigth } \\
\text { mandibular head }\end{array}$} & Male & 18 & 5.4917 & .77062 & \multirow{2}{*}{.866} & .999 \\
\hline & Female & 12 & 5.4425 & .77879 & & \\
\hline - A nteroposterior dimension of the left & Male & 19 & 5.8226 & .74800 & 323 & 973 \\
\hline mandibular head & Female & 12 & 5.5325 & .83567 & & \\
\hline - $\mathrm{H}$ eight of the mandible & Male & 20 & 13.678 & 2.6423 & 482 & 990 \\
\hline & Female & 12 & 12.991 & 2.6479 & & \\
\hline
\end{tabular}

on 38 landmarks and have concluded that no sexual dimorphism can be determined in subadults mandibles.

Much higher accuracy indexes (70-90\% accuracy) were obtained by Schutkowski, who has conducted a combined metric analysis from different parts of the skeleton, including the mandible. However, whenever the skeleton remains are not complete and assessment must be made from the mandible only, our results recommend the use of a nonmetric or qualitative analysis for the diagnosis of sex in subadults, this is also applied when specific populations' skeletal remainders exist or in those that one suspects of nutritional alterations (Suazo et al., 2008b, 2008c).

In conclusion, mandibles in the first year of life present little sexual dimorphism and is a quantitative approach seems not to be the best tool for sex identification with forensic purposes. $\overline{\text { SUAZO, G. I. C. .; ZAVANDO, M. D. A. \& SMITH, R. L. De- }}$ terminación del sexo en mandíbulas en el primer año de vida mediante una aproximación cuantitativa. Int. J. Morphol., 27(1):113116, 2009.

RESUMEN: Numerosos estudios han demostrado que las características esqueletales varían en las distintas poblaciones. Diversos autores indican que es posible la determinación del sexo en base a mandíbulas infantiles; sin embargo, existen escasos estudios morfométricos realizados en mandíbulas de niños brasileros. El propósito de este estudio fue analizar distintas dimensiones de mandíbulas y determinar aquellas de utilidad en el diagnóstico forense del sexo, en población infantil brasilera. Se utilizaron 32 mandíbulas de niños brasileros de entre 0 y 1 año de edad, de sexo conocido, pertenecientes a la colección de cráneos de la Universidade Federal de São Paulo (UNIFESP). Las mediciones mandibulares incluyeron ancho bicondilar, ancho bigonial, ancho mínimo y altura de la rama mandibular, longitud gonion- gnation, altura de la sínfisis mandibular y las dimensiones transversa y anteroposterior del cóndilo. Los datos obtenidos fueron sometidos 
al $\mathrm{t}$ test $(\mathrm{p}<0,05)$ y análisis de la función discriminante con SPSS. La mayoría de las dimensiones fueron superiores en hombres que en mujeres, con excepción del ancho mínimo de la rama mandibular $(0,2-0,16 \mathrm{~mm})$ y del diámetro transverso del cóndilo derecho $(0,16$ $\mathrm{mm}$ ). El diámetro anteroposterior de la cabeza mandibular resultó la más dimórfica de las medidas analizadas, aunque ninguna diferencia resultó estadísticamente significativa. El análisis de la función discriminante indicó que a pesar de las diferencias, éstas no permiten clasificar de acuerdo al sexo, en base a las variables cuantitativas analizadas. En conclusión, la mandíbula de niño en el primer año de vida presenta escaso dimorfismo sexual y no se recomienda el abordaje cuantitativo para la determinación del sexo con fines forenses.

PALABRAS CLAVE: Dimorfismo sexual; Determinación del sexo; Subadultos; Mandíbula.

\section{REFERENCES}

Cardoso, H. F. Sample-specific (universal) metric approaches for determining the sex of immature human skeletal remains using permanent tooth dimensions. $J$. Archaeol. Sci., 35:158-68, 2008.

Coqueugniot, H.; Giacobini, G. \& Malerba, G. L'utilisation de caracteres morphologiques dans la diagnose sexuelle des mandibules d'enfants: application à la collection ostéologique de Turín (Italie). Bull. mém. Soc. Anthropol. Paris, 14(1-2):131-9, 2002.

Franklin, D.; Oxnard, C. E.; O'Higgins, P. \& Dadour, I. Sexual dimorphism in the subadult mandible: quantification using geometric morphometrics. $J$. Forensic Sci., 52:6-10, 2007.

Holcomb, S. M. \& Konigsberg, L. W. Statistical study of sexual dimorphism in the human fetal sciatic notch. Am. J. Phys. Anthropol., 97:113-25, 1995.

Loth, S. R. \& Henneberg, M. Sexually dimorphic mandibular morphology in the first few years of life. Am. J. Phys. Anthropol., 115:179-86, 2001.

Merrot, T.; Panuel, M.; Bourliere, B.; Kathia, C.; Philip, N. $\&$ Dutour, O. Expression of sexual dimorphism in the fetal pelvic girdle. C. R. Acad. Sci., 324:137-41, 2001.

Rösing, F. W. Sexing immature human skeletons. J. Hum. Evol., 12:149-55, 1983.

Schutkowski, H. Sex determination of infant and juvenile skeletons: I. Morphognostic features. Am. J. Phys. Anthropol., 90:199-205, 1993.
Suazo, G. I. C.; Zavando, M. D. A. \& Smith, R. L. Blind test of mandibular morphology with sex indicator in subadult mandibles. Int. J. Morphol, 26(4):845-8, 2008a.

Suazo, G. I. C.; Zavando, M. D. A. \& Smith, R. L. Evaluating accuracy and precision in Morphologic traits for sexual dimorphism in malnutrition human skull: A comparative study. Int. J. Morphol., 26(4):876-83, 2008b.

Suazo, G. I. C.; Zavando, M. D. A. \& Smith, R. L. Sex determination using mastoid process measurements in Brazilian skulls. Int. J. Morphol., 26(4):941-4, $2008 \mathrm{c}$.

Correspondence to:

Prof. Dr. Iván Suazo Galdames

Departamento de Anatomía Normal

Universidad de Talca

Avenida Lircay s/n. Oficina N¹04

Talca - CHILE

Email: isuazo@utalca.cl

Received: 12-12-2008

Accepted: 08-01-2009 